\title{
ExxonMobil in Europe's Shale Gas Fields: Quitting Early or Fighting It Out?
}

\author{
Marc Naumann / Anne Philippi \\ Technical University of Applied Sciences, Wildau, Germany
}

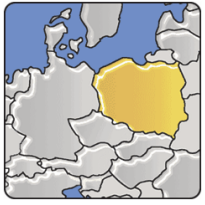

Abstract. This article focuses on the oil and gas supermajor, ExxonMobil, and its business in the unconventional gas field in Europe. The purpose was to investigate whether and how ExxonMobil runs its natural gas operations differently among European countries and possible reasons for divergent strategies. After a brief introduction of the firm, ExxonMobil's approach in Europe in general will be discussed. Two countries are in focus: Poland and Germany. The key finding is that the firm indeed has shown different approaches and strategies. In

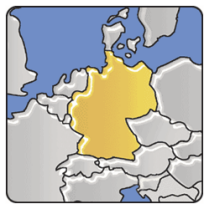
Poland, ExxonMobil faced a supportive, positive environment but quit quickly when its small investment resulted only in disappointing results. The firm, however, was a newcomer which had not much to lose. In contrast, its German unconventional gas operations are connected to broad conventional activities and are being defended by an extensive effort to win back public support.

Keywords: energy, energy policy, ExxonMobil, fracking, Germany, hydraulic fracturing, Poland, public acceptance, regulatory politics, shale gas, unconventional gas, USA

Author: The authors are M.A. candidates in the European Management program at Technical University of Applied Sciences, Wildau, Germany. They recently completed a semester at Monash University in Bandar Sunway, Malaysia.

\section{Introduction}

ExxonMobil, an American multinational corporation, is one of the most active companies in the field of unconventional gas exploration in Europe. The firm has pursued the new resource in multiple European countries in recent years, but it has also made surprising exits. The most prominent investments for this company were placed in Poland and Germany.

When ExxonMobil ran test wells in 2011 in Poland but then quit the country in 2012, it sent a disturbing message to investors, operators and energy policymakers in Poland, a country both rich in shale gas reserves and very supportive of shale gas development. By contrast, the firm has dug in its heels in Germany, which has much less shale gas to offer, a difficult regulatory environment and strong political opposition. When Germans turned hostile, the firm committed to fighting for public acceptance.

In Germany, ExxonMobil began exploration in 2008 but was forced to stop. Interestingly, ExxonMobil has proclaimed that "Germany (is) more likely to be the first shale gas producer" in comparison to Poland (Bergin, 2012). Poland and Germany are quite different in the way they pose challenges to ExxonMobil's business, and the firm has responded in different ways.

\section{The Company}

ExxonMobil Corporation, headquartered in Texas, is the largest publicly traded oil and gas producing company of the world; this "supermajor" in 2012 was ranked third in the Global Fortune 500 list (ExxonMobil, n.d.-a; Fortune, 2013). The company holds a great number of mining rights and resources around the world.

The firm has its roots in the legendary Standard Oil Trust which was broken up by a U.S. Supreme Court decision in 1911. Among the many legacy companies coming out of this split were two which, after some name changes, became Exxon and Mobil. In their early years, they focused on oil production and refining but by the 1950s expanded into the chemical industry (Vassiliou, 2009, p. XXXI). A change in U.S. antitrust law allowed the companies to merge in 1999. Today, ExxonMobil is a globally active multinational with many joint ventures (ExxonMobil, n.d.-b).

ExxonMobil has a century-long history in Europe, too, with Esso and Mobil being well-known consumer brands. Across Europe, the firm runs a broad upstream (exploration, production), downstream (refining, marketing, service stations), and chemical manufacturing business. Growth in demand for oil and gas products, together with continuously rising prices, has helped the firm expand enormously.

ExxonMobil became one of the leaders of the private oil industry, together with Chevron (USA), Royal Dutch Shell (UK/Netherlands), BP (UK), ConocoPhillips (USA) and Total (France). In the past decades, these corporations have faced stiff competition from state-owned firms such as Saudi Aramco, China's CNPC, Russian Rosneft, Iran's NIOC, PDVSA from Venezuela, Brazil's Petrobras and Malaysia's Petronas. In order to keep its leading position, ExxonMobil invests in finding new ways to reach and exploit resources. Deep water exploration is one path, as is unconventional gas. 
ExxonMobil is a classic oil "supermajor," but it has long moved into the natural gas business. In fact, today the firm produces as much gas as it produces oil (O'Keefe, 2012). It was, however, not among the pioneers of the unconventional gas players in North America, which were all smaller, independent firms that experimented with new methods. They did what the large companies did not dare to do because it seemed too difficult, too labor-intensive, and financially too expensive. As is now well known, only when they showed spectacular success, the big oil companies began to pay attention. By the mid-2000s, they began to realize the potential of the shale gas market.

So, like other major oil companies, ExxonMobil arrived late to the scene. It was through the 2010 takeover of XTO Energy, a specialized unconventionals firm and the largest gas producer (conventional and unconventional), that ExxonMobil firmly established itself as a natural gas major. The XTO buy was very controversial among ExxonMobil's shareholders and actually pushed Exxon's stock prices down, since fast profits were unsure; ExxonMobil's top management tried to explain that it was a new longterm investment and that the company had the financial resilience to do so: "We can be patient" (O'Keefe, 2012). Nevertheless, other big oil companies also bought unconventional gas producers, thus changing the commercial landscape, and introducing different approaches to the science, technology, and management of unconventional gas production.

ExxonMobil's acquisition of XTO Energy has been interpreted by some as a "dramatic shift in strategy," reshaping the firm; but others point to continuity in the firm's strategy to look for new horizons and a new project mix in the face of shrinking opportunities to replace oil reserves; even before the XTO acquisition, ExxonMobil had considerable investment in gas and other unconventional resources, such as Canadian oil sands, as well as worldwide facilities to produce and export liquefied natural gas (LNG) (Aeberman, 2012). It may also be said that the firm is increasingly wary of business risks in the international arena and is undergoing a "transformation from an integrated oil company to a capital and service provider," which means that it moves away from the traditional model of production and distribution and towards services like building plants and processing, adding value by providing capital and efficiency for external customers (Aeberman, 2012).

Globally, ExxonMobil is one of the most well-known firms. It is also one of the most criticized for a number of reasons, but certainly as a symbol for undue influence and power of multinational corporations, and as a symbol for pollution and climate-threatening business. The firm is a familiar enemy and target for the ecologically minded: "ExxonMobil is the environmental movement's antichrist" (Mower, 2010). Going into unconventional gas has increased the company's exposure to harsh criticism over the "fracking" technology, both in the U.S. and abroad, particularly in Europe. The firm, like others in the industry, has been reproached for denying environmental and health risks, and continuing to invest in fossil fuels rather than to contribute to a climate-friendly buildup of renewable energy and a low-carbon economy.

Thus, the firm makes a considerable effort to protect its reputation from attacks, invests in Corporate Social Responsibility projects, and commits to broad public communication about its value to economies and societies in the countries where ExxonMobil is active.

The firm's CEO, Rex Tillerson, offers a defensive and even somewhat laid-back attitude to public criticism over ExxonMobil's pursuit of new energy resources and methods. "We go through this every time we go to a new area to develop," he says, "it's just part of how society deals with having their energy needs met." He criticizes the attitude to avoid any risk because a constant governance by precautionary principle would undermine the economy: "If you want to live by the precautionary principle, then crawl up in a ball and live in a cave" (O'Keefe, 2012). He adds that in his view, his firm is actually more popular abroad than at home:

What I find interesting about the U.S. relative to other countries is in most every other country where we operate, people really like us. And they're really glad we're there. And governments really like us. And it's not just ExxonMobil. They admire our industry because of what we can do. They almost are in awe of what we're able to do. And in this country [USA], you can flip it around 180 degrees. I don't understand why that is, but it just is. (O'Keefe, 2012)

A mainstream view from Europe may not quite match Tillerson's perception. There is no lack of hostility towards ExxonMobil, and its unconventional gas engagement has increased rather than decreased the difficulties business strategy has to deal with.

\section{ExxonMobil in Europe}

Energy markets and political contexts vary across Europe. The potential for unconventional gas exploration also varies because geology and technical conditions are different, and some European countries have no sizable deposits of shale gas or other unconventionals. In general, ExxonMobil portrays itself as "one of Europe's largest oil and gas producers" and is "active in almost every European country" (ExxonMobil Corporation, n.d.-b), sporting regional websites for nearly 20 European countries (Belgium, Czech Republic, Finland, France, Germany, Iceland, Ireland, Italy, Luxembourg, Netherlands, Norway, Poland, Portugal, Spain, Sweden, Turkey, and the United Kingdom). But this does not mean that the company is doing business in unconventional gas everywhere.

The firm has pursued this special business in Poland, Germany, Ukraine, Hungary and Turkey. However, for several reasons and factors, ExxonMobil has already quit activities in some countries, or no concrete investment decision has been communicated. In Hungary, ExxonMobil formed a joint venture with the Hungarian energy company Falcon Oil \& Gas in 2008/09. But after disappointing test results, Exxon left the partnership and stopped its tests (Brenner, 2009; NaturalGasEurope.com, 2012b). ExxonMobil was reported in 2012 and 2013 to hold talks with Turkish Petroleum Corporation (TPAO) for shale gas exploration in Turkey (Hürriyet Daily News, 2013). In Ukraine, ExxonMobil and the state-owned Naftogaz signed a deal in early 2011 to cooperate in development and exploration of shale gas reserves. Ukraine has the fourth-largest deposits of shale gas. Other big companies such as Shell, Chevron, Total, Eni and EdF have rushed to compete, which makes it difficult for Exxon to get the real pioneer role in this country. Nevertheless the company has the necessary resources and funds to hold a solid position in Ukraine (n.a., 2011b; Reuters, 2011; Tuohy \& Bulakh, 2013). Even though ExxonMobil's performance on the stock market had been rather poor compared to the Dow Jones Industrial Average, it generated gains above 10\% in 2013 (Caplinger, 2013) and its revenues and profits are among the highest in the world (see Global Fortune 500 list).

ExxonMobil makes a Europe-wide effort to communicate on unconventional gas opportunities and industrial processes. Its Brussels office continuously participates in discussions and consultations by the EU institutions, collaborating with industry associations such as OGP, the International Oil and Gas Producers Association, representing upstream interests. Next to its corporate global and national websites, it has hired the Brussels-based public affairs agency Fleishman-Hillard to run, from 2011, a web platform in English, German, French and Polish (europeunconventionalgas.org, europaunkonventionelleserdgas.de, gaznonconventionnelseurope.org, europagazniekonwencjonalny.pl). Probably because of this, the firm has not joined the younger cross-industry "Shale Gas Europe" initiative and web platform (shalegas-europe.eu), started in 2012 by London- and Brussels-based FTI Consulting and supported by Chevron, Cuadrilla, Halliburton, Shell, Statoil and Total. Both web platforms are, however, quite similar 
in their positive promotion of unconventional gas and in their attempt to refute negative arguments.

Only in Germany, a country deeply skeptical of unconventional gas and "fracking" in particular, has ExxonMobil attempted to soften critical public opinion by a lengthy, elaborated and broadly publicized local stakeholder consultation process combined with extensive independent scientific work: the "Information and dialogue process of ExxonMobil about the safety and environmental impact of fracking technology for natural gas from unconventional sources" (Krüger, 2011; Schmitz, 2012).

\section{Poland: Testing and Quitting}

Poland is one of the few countries in Europe which has decidedly come out in favor of shale gas and tries to provide firms with a positive environment. The country wants to be a forerunner in the unconventional gas sector and is ready to activate stakeholders to deflect potential EU regulatory restrictions on the sector.

When the European Commission, namely the Directorate-General for Environment, in 2013 started a public consultation, it received most replies from Poland's institutional, business and citizen participants. In comparison, many other countries care a lot less (European Commission DG Environment, 2013, p. 2).

Poland also showed the highest share of participants in the consultations to be in favor of developing unconventional fossil fuels. Overall, Polish participants, by a 95 percent majority, basically said yes to unconventional gas in regard to this survey (European Commission DG Environment, 2013, p. 6). While these results should be taken with caution, and both European and domestic public opinion polls show a different picture, generally unconventional gas has enjoyed relatively high support among elites and the public.

After early studies showed that Poland could be among Europe's lands with the largest shale gas capacity, the government started to attract many foreign companies to explore the potential (CNN.com, 2012; Strzeleck, 2013). Compared to Germany with its twelve exploration concessions, Poland with 109 concessions seemed to be on the right way, and general opinion towards "fracking" was not as bad as in other European countries (Shale Gas Europe, 2013a, 2013b).

Poland's main strategic target is to gain higher independence from Russian gas imports. Furthermore, the country hopes that unconventional gas could improve the economic situation, state revenues, and even enable the country to export gas while still diversifying energy supply (Speak, 2013). Currently, Poland satisfies around 90 percent of its energy needs by coal (CNN.com, 2012). Nevertheless, a movement against the new technology has developed, especially among rural communities fearing for the farming business and the environment (MariCW, 2013). Since the movement against is comparatively small in regard to other European countries, and a supportive environment for gas companies, ExxonMobil followed the Polish invitation (CNN.com, 2012).

The reasons why Poland invited big companies like ExxonMobil are obvious. Most of them have great experience in exploring the potential of unconventional gas fields. Furthermore they have the financial means to cope with the initial phase of such new technology (Sreekumar, 2013).

Exxon started with two test drillings in Poland in 2011. The regions in which Exxon was able to get concessions are regarded as the most profitable. However, there was also strong competition during the first round of Polish concessions (Trefis Team, 2011).

While ExxonMobil happily communicated with the media, which showed great interest in this major firm's enterprises, it only offered limited opportunities for citizens to find information or participate. The company did set up a Polish-language version of its European website, europagazniekonwencjonalny.pl.

But only one year later after tests had begun, ExxonMobil left the country after the company completed testing at two wells. The company sold the concessions to state-owned PKN Orlen and stated that it would pull out from Poland, ending all exploration (NaturalGasEurope.com, 2012a). There were multiple reasons for this step, although some media oversimplified them. Some observers saw a direct connection between resignation in Poland and a new deal in Russia, where the company could explore for tight oil in Siberia (NaturalGasEurope.com, 2012a). ExxonMobil itself justified the decision with unsatisfactory results from the test drillings. These had shown that Polish shale gas is not brittle enough to reach commercially sufficient gas rates. The cost for producing gas would be too high and uncompetitive (NaturalGasEurope.com, 2012b). The firm also said that it is in the belief that Germany has better chances to become a shale gas producer than Poland. Part of this justification was existence of a better developed industry in Germany, whereas Poland is only at the beginning and the whole gas industry is completely new (Bergin, 2012; The Economist, 2013). One should also look to the fact that unconventional gas prospects had been exaggerated and overdrawn. There is no doubt there is a certain amount which would mean high energy supply security for Poland. But the early estimates looked much more brilliant than the revised data later (Shale Gas Europe, 2013b). This combined with difficulties to apply techniques and technology from the U.S. at Polish sites, and a limited professional service industry transferable to Polish shale gas; obviously the transatlantic transfer proved less easy than expected, and many adjustments have to be made (NaturalGasEurope.com, 2012a).

Next to geological and technical problems, there were also policy problems. Regulations and laws for this new technology got stuck in the political process (Speak, 2013). In particular, uncertainty about upcoming tax regulations may have Exxon to rethink: The government discussed plans to tax profits up to 40 percent (Sreekumar, 2013). Even withdrawal of these plans could not convince Exxon to further explore shale gas in Poland. As other companies quit Poland, the government decided to provide tax releases for shale gas exploring companies till 2020 (Speak, 2013). Exxon also stated that the existence of a mandatory partner like the National Energy Minerals Operator (NOKE) would be uncomfortable. This partner would act like a state-owned company that yields its profits to the state treasury (NaturalGasEurope.com, 2012c).

In addition, the timeframe between acquiring a concession and getting the permission to drill was too long and sometimes too uncertain for companies like Exxon. Some companies did not get the wanted or needed numbers of concessions, whereas others had the right number of concessions but did not get drilling licenses due to intransparent decisions (Sreekumar, 2013).

Actions taken by the Polish government in order to keep as many investors as possible came too late for ExxonMobil. The government became more sensitive towards its policymaking process. It has emphasized that businesses should not fear the regulatory framework, and that it hopes to convince companies that have left to come back (NaturalGasEurope.com, 2012c). Poland is against a regulation about unconventional gas on the EU level. The government argues that every country should handle laws and regulations on its own (Shale Gas Europe, 2013b).

\section{Germany: Holding on, Fighting}

Compared to Poland, the German energy market and system shows very different characteristics. Germany has a fairly diversified energy supply, but a major feature is a high degree of import 
dependency well above EU average (Ćwiek-Karpowicz, Gawlikowska-Fyk \& Westphal, 2013). As the largest EU member state with a very advanced industry, Germany also needs the most energy. The country, which historically is a large-volume gas user for industry purposes, heating, and recently also electricity generation, has a well-developed gas pipeline infrastructure. Still bound by long-term contracts, Germany imports high volumes of gas and oil from Russia, Norway, and the Netherlands (Ćwiek-Karpowicz et al., 2013). But Germany, which also has a long history of producing its own gas (albeit not nearly enough to be self-sufficient), also counts among the countries in which sizeable unconventional deposits of natural gas have been identified. This has not led to enthusiasm at all, not even when the "Energiewende" debate made it clear that innovative replacements for outgoing nuclear plants have to be found, and that energy prices are expected to increase steeply - despite big investments in renewable energy production from photovoltaics to wind farms to biomass.

German energy policymakers are indeed very skeptical and undecided in regard to "fracking" and its related risks and benefits. There are many organized opponents. However, industrial leaders and other groups have shown some quite solid support for unconventional gas development, not the least to keep Germany's high tech industries and manufacturing internationally competitive.

ExxonMobil recognized Germany as a great and important market, although it has to face strong obstacles for its unconventional gas business. In recent years, the company has stepped up its communication efforts to make elites and the public aware of the significance of domestic natural gas production - conventional and unconventional.

\section{ExxonMobil has a market position to defend}

This seems very plausible. While Germany imports most of its gas and generates only twelve percent on its own, of the German domestic production, ExxonMobil has a share of nearly 70 percent. As figure 1 shows, the firm is much bigger in output than competitors RWE-Dea, GdF Suez and BASF Wintershall - ExxonMobil is the largest natural gas producer and supplier in Germany (see figure 1) (ExxonMobil Central Europe Holding GmbH, n.d.-a). The country's dominant operative company in natural gas production is actually BEB Erdgas und Erdöl (BEB), headquartered in Hannover, Lower Saxony; BEB, which is historically a true German firm going back to the $19^{\text {th }}$ century, is a $50 / 50$ joint venture of Shell and Esso (Exxon), but its facilities are all operated by a direct subsidiary of ExxonMobil (BEB, 2013).

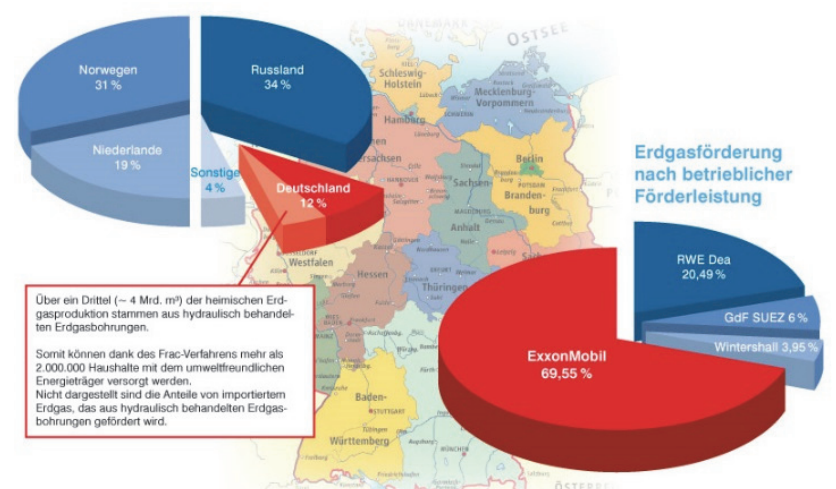

Figure 1: Supply of the German gas market 2012 (ExxonMobil Central Europe Holding GmbH, n.d.-b)

German conventional gas reserves and production have continuously decreased, despite relatively intensive technical attempts to improve output. For producers, the challenge is to replace old sources by new ones - and here, unconventional gas comes in.
"Fracking," however, is a very old story in Germany. In the Northwestern state of Lower Saxony (Niedersachsen), the country's center of gas production, hydraulic fracturings has been used for 50 years - counting some 300 "fracs" to improve conventional and tight gas drilling. Lower Saxony gave its last permission to "frack" in 2011. In fact, a significant share of domestic gas production comes from "fracked" wells (including many of ExxonMobil's), and, as the state's mining authority emphasizes, not ever has environmental damage been recorded on any of these (Land Niedersachsen, 2013, p. 3).

Hydraulic fracturing was a technology only discussed in specialist circles - with some exceptions. In 2006, when ExxonMobil opened a new gas reservoir through "fracking," the firm even received a high-profile "Germany - Land of Ideas" award for its feat of engineering, celebrated with hundreds of local dignitaries. In those days, before controversy started, "fracking" was a reason to party, not to protest (Müller, 2013).

What is new in Germany is unconventional gas, not "fracking" as such. Yet, exploring for shale gas demands much greater volumes of hydraulic fracturing in a larger industrial context, and neither German mining authorities nor scientists have experience with such projects. On the other hand, preliminary studies estimate that the 700 to 2,300 billion cubic metres are much greater than the old proven domestic reserves; to get realistic, reliable data, explorative drilling using "fracking" would be necessary (Land Niedersachsen, 2013, p. 3).

Since 2008, Exxon has begun to explore natural gas reserves in shale and coalbeds in the states of Lower Saxony and North RhineWestphalia (ExxonMobil Central Europe Holding GmbH, n.d.-d). The main focus in Germany still lies on test and exploration drillings. For Exxon, this means six drillings in shale have been realized and three additional shale gas projects are planned in Lower Saxony (ExxonMobil Central Europe Holding GmbH, n.d.-c).

The legal framework is extensive. It encompasses multiple German authorities and laws which have to be consulted, such as the federal mining law (Bundesberggesetz, BbergG) in order to get a permission, state mining regulations, and various environmental regulations (e.g. water legislation) (ExxonMobil Central Europe Holding GmbH, n.d.-f).

ExxonMobil has a national market position to defend. Locally, the firm has had a solid and positive reputation as a responsible, community-anchored employer in economically challenged regions of the rural, less populated and less industrialized Northwest. ExxonMobil was the quintessential corporate citizen, a generous charitable neighbor who helped small towns to finance a fire truck or a childrens' therapy center when they needed it. The gas boom was a great time for the municipalities, also because they cashed in. The firm was a welcome taxpayer: In the state of Lower Saxony alone, it not only paid tax to federal and state authorities but to up to 80 local governments, who lived quite happily with the rigs that ExxonMobil put up to drill (Müller, 2013).

But then, the shale gas controversy hit Germany - with much credit going to German media picking up the dramatic messages of the U.S. film, Gasland. In many places public opinion capsized "with remarkable speed," as the conservative national daily Frankfurter Allgemeine noted: Local politicians and dignitaries disassociated themselves from the firm. They suddenly refused gifts in the name of Corporate Social Responsibility, and, under pressure from new anti-fracking groups, began to draft resolutions against their former benefactor in local councils (Müller, 2013).

In the national arena, ExxonMobil has experienced an even more negative and politicized backlash in recent years as the most prominent target for environmental groups and new grassroots initiatives, such as the "Gegen-Gasbohren" network. Media reporting about failing and faulty drilling and accidents, connected to unconventional gas or not, in Germany or abroad, fed the smoldering fire (NDR, 2011; Krüger, 2011; Panorama, 2011). 


\section{A new approach: campaign for acceptance}

ExxonMobil's managers recognized they had a problem on their hands. The company has responded with broad, numerous communication initiatives. Exxon is not afraid or shy to communicate its activities in the public and it also wants to solve arising problems openly. ExxonMobil representatives spend considerable time in local hearings and citizen forums, where they sometimes face aggressive questioning and reproachful comments (Klemp, 2010; Meier, 2010; n.a., 2011a).

It has initiated an advertising campaign, taking out full-page ads in leading daily and weekly newspapers and magazines, and has run a television campaign, with 30 -second spots directly placed before Germany's most popular nightly news, "Tagesschau".

These spots - just like various other media - prominently feature Exxon employees (mostly engineers) as testimonials; they not only promoted the potential of Germany's domestic gas supply but also, in a serious tone, address public concerns. They used words like future, environmental friendliness or safe and responsible. Needless to say, this advertising provoked a stir among critical bloggers and social media users, trying to counter the corporate messages with commentary and analysis that the firm offers "unconventional half-truths" (n.a., 2011c).
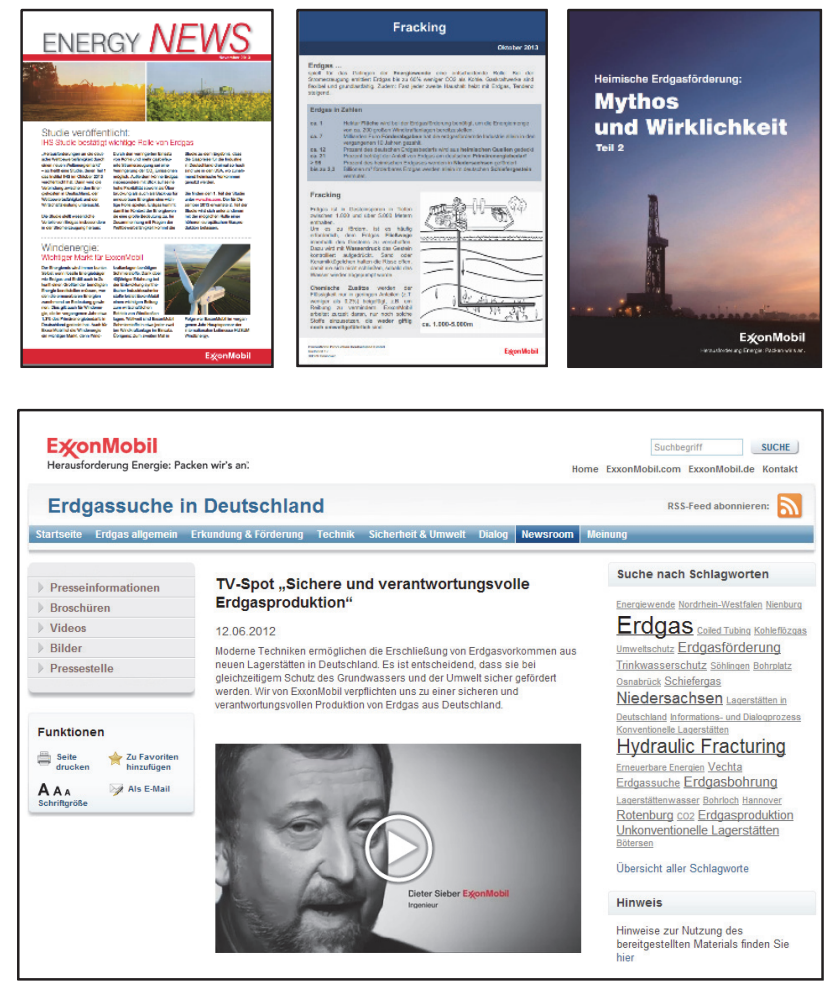

Figure 2: Samples of German ExxonMobil media-brochure covers and TV spot with employee testimonial on a special-interest website, erdgassuche-in-deutschland.de

The company has coined clever slogans, used in various media and in press interviews, such as "Germany needs natural gas, and Germany has natural gas." The message is simple but effective we have it, so let's go get it (ExxonMobil Central Europe Holding GmbH, n.d.-a; von Petersdorff, 2013).

Apart from a German-language version of its European website (europaunkonventionelleserdgas.de), the firm's Hamburg-based Public and Government Affairs department, aided by a press spokesman in Hannover, also runs a website dedicated to "the search for natural gas in Germany" (erdgassuche-in-deutschland.de). With some extension to other electronic channels (YouTube, Twitter), Exxon supplies plenty of online materials, photos, graphic charts, fact sheets, data and brochures ("Domestic gas production: myth and reality"); it also invites users for interactive blogging in an opinion section. A continuous flow of news about even detailed works on gas sites comes out of the news section, and press "canards" with incorrect information are responded to regularly. While these media channels and messages might still be considered quite conventional, ExxonMobil also committed serious resources to an extensive and openly publicized participatory stakeholder consultation process, combined with a "neutral" risk assessment of hydraulic fracturing. As was reported, the company committed about one million euros to the innovative effort (Tenbrock, 2011).

There were no flashy ads and marketing-styled communications; instead, it took a decidedly down-to-earth, earnest path in three segments - "Wissen und Forschen," knowledge and science, „Reden und Einfluss nehmen,“ speaking and influencing, and "Fragen und Kommentieren," questioning and commenting.

This setup had a lengthy formal title: "Informations- und Dialogprozess der ExxonMobil über die Sicherheit und Umweltverträglichkeit der Fracking-Technologie für die Erdgasgewinnung," or in English: information and dialogue process by ExxonMobil about safety and environmental compatibility of the fracking technology for natural gas extraction.

This internationally unique tool started in April 2011 and was operative until April 2012, with subsequent communications continuing. ExxonMobil representatives continually observed the process but, for the most part, stood out of the way. Some company engineers and scientists answered firm-specific questions, and at the opening and end, ExxonMobil Europe CEO Gernot Kalkoffen spoke some friendly words, but overall the firm took a low profile, avoiding criticism it was steering the process.

The "info-dialogue's" basic credibility-enhancing element was the concept of an independent and neutral panel of experts from different disciplines, formed to investigate potential risks for a final report. Obviously, the neutrality of the experts would be questioned. ExxonMobil only selected experts that had never before worked for the firm or the natural gas industry.

Their efforts would also be put under scientific peer review. Their work was public and was observed with a critical eye from a working group consisting of various social actors including community leaders, water utility representatives, farmers' associations, citizen groups and even clerics and religious community representatives. They were to work with the experts, collecting and formulating questions which the scientists would try to answer and later debate with the other stakeholders.

The whole process was documented on a website, dialogerdgasundfrac.de (see screenshot, figure 3), and facilitated by professional moderators from an Osnabrück consultancy specializing in citizen dialogues (Ewen, Borchardt, Richter \& Hammerbacher, 2012).

In April 2012, the expert panel presented its comprehensive risk assessment in a large public conference. This completed the twelve-month "info-dialogue". The experts did not see any objective reasons to totally ban exploration and production of unconventional gas using hydraulic fracturing.

Their final report, however, included elaborate recommendations and warnings: there are major and minor risks, including threats to water; the extraction of unconventional gas leads to more emissions than that of conventional gas; "frac" fluids should be used without certain dangerous chemcials; "fracking" should not be applied in at-risk territory; some laws should be changed to be more restrictive; more science must be generated; and in any case, all projects should undergo extensive stakeholder consultations and planning procedures. The scientists clearly said: proceed with high caution, not everywhere and not under all circumstances (ExxonMobil Central Europe Holding GmbH, n.d.-i). 
The firm documented the whole process and had its representatives present it at various events. But it framed it, as could be expected, in all-positive terms. News media generally reported in a friendly way, particularly local and regional newspapers and broadcasting. But since all was public, many critical voices echoed across media and the Internet. For example, since ExxonMobil paid for the complex and costly procedure, questions came up how independent the work of the panel of nearly 40 scientist really was and whether Exxon influenced them, perhaps indirectly. Experts and the company did not disclose how much the scientists and their reviewers were paid. So this left room for speculation. Beyond such details, some of course put a question mark behind the intentions and purposes of the total exercise.

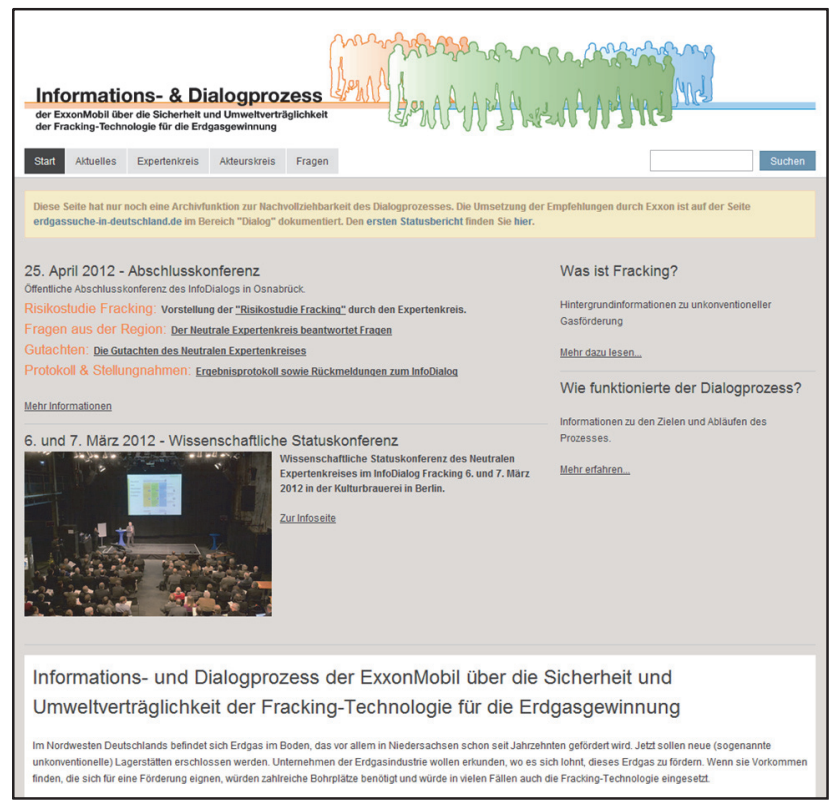

Figure 3: Website dialog-erdgasundfrac.de

In one harshly critical report, the left-leaning, green-minded Berlin national daily newspaper taz debunked the "pseudo-dialogue" as "cosmetic" and "manipulative." The process was meant to give new legitimacy to ExxonMobil's operations, now enjoying the blessing of serious scientists. It created an "illusion" of equality when small-town mayors and simple farmers conversed with eminent researchers or mighty corporate leaders. The taz pointed out that discussion topics were systematically limited to "fracking;" it was not an arena to debate energy policy, how fossil fuels competed with renewables, or whether that gas was really needed, or who makes a profit from continuing to produce and consume gas. Fundamental questions about power in society were not on the table: neither the pre-democratic principles behind Germany's mining laws which gives priority to resource extraction, not ecology or citizen participation, nor the power of corporate lobbyists setting the stage for the public agenda (Seyfert, 2012).

Nevertheless, the one-year process which saw ExxonMobil pay scientists to publicly write up a long list of no-go areas and business-restricting recommendations impressed even some of the most vocal critics. As one astounded senior policy analyst from the U.S. Natural Resource Defense Fund, a well-organized antifracking green organization, said: "Can anyone imagine ExxonMobil funding a similar project in the U.S.?" (Mall, 2012).

ExxonMobil also tried to win over skeptics with substantial commitments. Not only does the firm support full disclosure of chemicals used in the hydraulic fracturing process, in one 2012 interview with business magazine WirtschaftsWoche, ExxonMobil Europe CEO Gernot Kalkoffen announced that his firm would reduce the percentage of potentially dangerous or toxic chemicals in the fluids to zero by 2013 (Dürand \& Matthes, 2012).

At the moment, exploration is on hold. As a de facto moratorium had interrupted work, it is still unclear what the federal and state governments will change in the legislative and regulatory framework. ExxonMobil has committed to educational efforts and to be open and communicative about public acceptance problems to safeguard its investments, as the firm does not want to lose its dominating position in the German upstream gas market.

So far, the outcome is uncertain, but ExxonMobil has set a new standard for itself and the industry which diverges greatly from what it has undertaken in Poland or in any other country.

\section{Conclusion}

ExxonMobil showed impressively different approaches in Poland and Germany. They offer quite different business environments. At first view, Poland's seemed so much more promising and supportive, and an easy context to pursue unconventional gas opportunities. The firm's exit from Poland was a shock for the country and the government which had placed great hopes on foreign investors. Perhaps the new deal with Russia for tight oil in Siberia was a good reason to reshuffle priorities in the face of disappointing test runs in Poland.

Maybe the company, and also the Polish government handing out concessions, was a little too naïve to think that it would be possible to quickly find commercialization of Polish reserves. This case shows that even if a government strongly comes out in favor and creates a good environment for companies like Exxon, this cannot guarantee success when other technical and business decisions are more important. Poland may have looked like a "fracking heaven" (Economist, 2013) but to some extent the country was not ready to deal with all the new challenges.

In Germany, ExxonMobil found a much more uncomfortable environment. Yet there were also some unique advantages for the firm as a dominant and well-established player in domestic conventional gas production. ExxonMobil's upstream gas business in Germany has a 100-year-old history. The contrast could not be greater: ExxonMobil was a newcomer to Poland's rush for gas, one competitor among many. It did not lose much when it quit the quest for the prize. Germany is a difficult place, too, but the nontechnical risk may in the end prove manageable, as the company has political leverage and the will to fight in familiar territory.

ExxonMobil might have had some reasons to quit Germany's unconventional gas base, as it had done in Poland. But one should keep in mind that the firm saw Germany to be more likely to become a shale gas producer than Poland (Bergin, 2012).

When the German public, at various levels, turned hostile, it pushed ExxonMobil to a new approach. Instead of giving up, the company developed ideas to provide a higher level of transparency, to work with information and argumentation to educate the public, and make concessions to the greater political demand for responsible operations. ExxonMobil fell far from erasing all doubts, of course, and this could hardly work within a short period, or in the face of a strong green movement which is generally against continuing and growing use of fossil fuels, domestic or elsewhere. Governments in Germany have made no effort to make it easier to operate unconventional gas facilities; quite the contrary. More regulation is on the way, but ExxonMobil has tried to show that it is part of the solution rather than part of the problem.

Given that the German governments and political parties are anxious to develop renewable energies as a high priority, ExxonMobil could never have expected a fossil fuel enthusiasm as has been found in Poland. But that was always clear. On the other hand, the "Energiewende" debate has opened up opportunities to 
talk about domestic supply as a matter of high national and economic concern. That, at least, is something that Poland and Germany have in common.

\section{References}

Aeberman (2010, 22 February). ExxonMobil's acquisition of XTO Energy: the fallacy of the manufacturing model in shale plays. The Oil Drum. Retrieved 27 November 2013 from http://www.theoildrum.com/node/ 6229

BBC News. (2013, May 8). North American firms quit shale gas fracking in Poland. Retrieved July 15, 2013, from http://www.bbc.co.uk/news/business-22459629

BEB Erdgas und Erdöl (2013). Das Unternehmen. Retrieved 27 Nov 2013 from http://www.beb.de/about.html

Bergin, T. (2012, February 20). Exxon tempers European shale gas enthusiasm. Reuters. Retrieved July 15, 2013, from http://uk.reuters.com/article/2012/02/20/exxon-shale-europeidUKL5E8DK6TJ20120220

Brantley, S. \& Meyendorff, A. (2013, March 13). The Facts on Fracking. Retrieved July 12, 2013, from http://www.nytimes.com/2013/03/14/opinion/global/the-facts-on-fracking.html?pagewanted $=$ all

Brenner, N. (2009, August 10). ExxonMobils quits Hungarian shale test. Upstream. Retrieved May 14, 2013, from http://www.upstreamonline.com/live/article1241433.ece

Caplinger, D. (2013, November 29). Why ExxonMobil Has Lagged Behind Chevron and the Dow Jones Industrials in 2013. Retrieved February 1,2014 , from $\mathrm{http} / / / \mathrm{www}$.fool.com/investing/general/2013/11/29/why-exxon-mobil-has-lagged-behind-chevron-andthe.aspx

Charlez, A. (1997). Rock Mechanics. Paris: Editions Technip. Retrieved from

http://books.google.de/books?id=NigwG_BYRsYC\&pg=PA239\&redir esc $=\mathrm{y} \# \mathrm{v}=$ onepage $\& \mathrm{q} \& \mathrm{f}=$ false

Choursina, K. \& Bauerova, L. (2013, 5 November). Ukraine edges toward cheaper gas with Chevron, Exxon deals. Washington Post. Retrieved 27 November 2013 from

http://washpost.bloomberg.com/Story?docId=1376-MVSKED6JIJXM0115PLEE6AEPRU35RLTKSM6CMR7N

CNN.com. (2012, May 29). Poland has great "fracking" potential with shale gas reserves. Retrieved July 14, 2013, from http://edition.cnn.com/2012/05/28/world/europe/eye-on-poland-shale

Ćwiek-Karpowicz, J., Gawlikowska-Fyk, A., \& Westphal, K. (2013). German and Polish energy policies: is cooperation possible? PISM Policy Paper, (49).

dgw/AFP. (2013, May 21). Bundesregierung bremst Brüssel beim Fracking aus. Retrieved July 15,2013 , from http://www.welt.de/wirtschaft/energie/article1 16395808/Bundesregierung-bremst-Bruessel-beim-Fracking-aus.html

Dürand, D. \& Matthes, S. (2012, April 8). Fracking: ExxonMobil will Schiefergas ohne Gift fördern. Retrieved February 17, 2013, from http://www.wiwo.de/unternehmen/energie/fracking-exxonmobil-willschiefergas-ohne-gift-foerdern/6959888.html

Economist. (2013, June 23). Energy in Poland: Fracking heaven. Retrieved July 15, 2013, from http://www.economist.com/node/18867861

European Commission DG Environment. (2013, June 7). Presentation of the results of the public consultation "Unconventional fossil fuels (e.g. shale gas) in Europe." Brussels.

European Onshore Energy Association. (n.d.). How it works. Retrieved July 12, 2013, from http://eoea.eu/index.php/de/wissenszentrum/hydraulisches-aufbrechen/how-it-works.html

Ewen, C., Borchardt, D., Richter, S. \& Hammerbacher, R. (2012). Hydrofracking Risk Assessment: Executive Summary: Study concerning the safety and environmental compatibility of hydrofracking for natural gas production from unconventional reservoirs. Retrieved from http://dialog-erdgasundfrac.de/sites/dialogerdgasundfrac.de/files/Ex_HydrofrackingRisk_Assessment_120611.pdf

Exxon Mobil Corporation. (n.d.-a). Unconventional Gas in Europe. Retrieved July 14, 2013, from http://www.europeunconventionalgas.org/new-home/unconventional-gas/unconventional-gas-in-europe
Exxon Mobil Corporation. (n.d.-b). About us. exxonmobileurope.com. Retrieved July 12, 2013, from http://www.exxonmobileurope.com/Europe-English/about.aspx

ExxonMobil. (n.d.-a). Hydraulic fracturing. Retrieved July 14, 2013, from http://www.exxonmobil.com/Corporate/energy_production hf.aspx

ExxonMobil. (n.d.-b). What we do. Retrieved July 14, 2013, from http://www.exxonmobil.com/Corporate/about_what.aspx

ExxonMobil. (n.d.-c). Who we are. Retrieved July 14, 2013, from http://www.exxonmobil.com/Corporate/about_who.aspx

ExxonMobil. (n.d.-d). Upstream. Retrieved July 14, 2013, from http://www.exxonmobil.com/Corporate/about_what_upstream.aspx

ExxonMobil Central Europe Holding GmbH. (n.d.-a). Was bedeutet horizontales Bohren und Hydraulic Fracturing? EuropaUnkonventionellesErdgas.de. Retrieved July 12, 2013, from http://www.europaunkonventionelleserdgas.de/home/der-prozess/was-versteht-manunter-horizontalem-bohren-und-hydraulic-fracturing

ExxonMobil Central Europe Holding GmbH. (n.d.-b). Erkundung und Förderung. Retrieved July 14, 2013, from http://www.erdgassuche-indeutschland.de/erkundung_foerderung/index.html

ExxonMobil Central Europe Holding GmbH. (n.d.-c). Erdgas allgemein. Erdgassuche in Deutschland. Retrieved July 13, 2013, from $\mathrm{http}: / /$ www.erdgassuche-in-deutschland.de/erdgas_allgemein/index.html

ExxonMobil Central Europe Holding GmbH. (n.d.-d). Erdgas allgemein: Versorgung des deutschen Gasmarktes 2012. Retrieved July 14, 2013, from http://www.erdgassuche-in-deutschland.de/images/cm/daten_fakten-2.jpg

ExxonMobil Central Europe Holding GmbH. (n.d.-e). Erkundung und Förderung. Erdgassuche in Deutschland. Retrieved July 13, 2013, from http://www.erdgassuche-in-deutschland.de/erkundung_foerderung/index.html

ExxonMobil Central Europe Holding GmbH. (n.d.-f). Erkundung. Erdgassuche in Deutschland. Retrieved July 13, 2013, from http://www.erdgassuche-in-deutschland.de/erkundung_foerderung/erkundung/index.html

ExxonMobil Central Europe Holding GmbH. (n.d.-g). Rechtliche Rahmenbedingungen. Erdgassuche in Deutschland. Retrieved July 13, 2013, from http://www.erdgassuche-in-deutschland.de/erkundung_foerderung/rechtliche_rahmenbedingungen/index.html

ExxonMobil Central Europe Holding GmbH. (n.d.-h). Dialog. Erdgassuche in Deutschland. Retrieved July 14, 2013, from http://www.erdgassuche-in-deutschland.de/dialog/index.html

ExxonMobil Central Europe Holding GmbH. (n.d.-i). Informations- und Dialogprozess. Erdgassuche in Deutschland. Retrieved July 13, 2013, from http://www.erdgassuche-in-deutschland.de/dialog/informations_dialogprozess/index.html

ExxonMobil Central Europe Holding GmbH. (n.d.-j). Förderung. Erdgassuche in Deutschland. Retrieved July 13, 2013, from $\mathrm{http}: / /$ www.erdgassuche-in-deutschland.de/erkundung_foerderung/foerderung/index.html

Fortune. (2013, January). Fortune Global 500. Retrieved July 14, 2013, from http://money.cnn.com/magazines/fortune/global500/index.html

Headwater Magazine. (2012). A history of hydraulic fracking. Retrieved July 12, 2013, from http://oberlinheadwaters.com/?p=251

Hürriyet Daily News (2013, 23 July). Shale gas; risks and opportunities for Turkey. Retrieved 27 November 2013 from http://www.hurriyetdailynews.com/shale-gas-risks-and-opportunities-for-turkey.aspx?PageID $=238 \& N I D=51197 \&$ NewsCatID $=402$

Keating, D. (2012, February 2). EU shale-gas debate hots up. EuropeanVoice.com. Retrieved February 11, 2013, from http://www.europeanvoice.com/article/imported/eu-shale-gas-debate-hots-up/73438.aspx

Klemp, C. (2010, November 24). Bürger bohrten nach: ExxonMobil drei Stunden im Kreuzverhör. Ruhrnachrichten.de. Retrieved March 1, 2013, from http://www.ruhrnachrichten.de/nachrichten/region/hierundheute/nams/Buerger-bohrten-nach-ExxonMobil-drei-Stundenim-Kreuzverhoer;art1757,1105310

Krüger, J. (2011, July 15). ExxonMobil stolpert über eigene Strategie und reißt RWE DEA gleich mit. Unkonventionelle Gasförderung. Retrieved July 12, 2013, from http://www.unkonventionelle-gasfoerderung.de/2011/07/15/exxonmobil-stolpert-ueber-eigene-strategie-undreisst-rwe-dea-gleich-mit/

Land Niedersachsen, Landesamt für Bergbau, Energie und Geologie (2013). Erdöl und Erdgas in der Bundesrepublik Deutschland 2012. 
Retrieved 27 November 2013 from http://www.lbeg.niedersachsen.de/portal/live.php?navigation_id=655\&article id $=936 \&$ psmand $=4$

Mall, A. (2012, November 10). The latest science from Europe on fracking. The energy collective. Retrieved July 12, 2013, from http://theenergycollective.com/amymall/122906/latest-science-europe-fracking

MariCW. (2013, June 9). Poland Farmers Stand Up Against Chevron to Fight Fracking. Retrieved July 14, 2013, from http://occupythepipeline.blogspot.de/2013/06/poland-farmers-stand-up-against-chevron.html

Meier, B. (2010, October 12). Informationsabend: „Erprobte Technik läuft ohne Zwischenfälle“. NWZonline.de. Retrieved March 1, 2013 , from http://www.nwzonline.de/vechta-kreis/erprobte-technik-laeuftohne-zwischenfaelle_a_1,0,702335248.html

Mower, J. (2010, 13 December). The very long-term view of ExxonMobil. Platts: The Barrel [blog]. Retrieved 27 November 2013 from http://blogs.platts.com/2010/12/13/the_very_long-t/

Müller, C. P. (2013, December 5). Debatte über Gasförderung: Fracksausen. FAZ.net. Retrieved from http://www.faz.net/aktuell/politik/inland/debatte-ueber-gasfoerderung-fracksausen-12180177.html

n.a. (2011a, February 2). Lünne: Exxon Mobil will Dialog mit ErdgasGegnern. Retrieved March 1, 2013, from

http://www.nwzonline.de/politik/niedersachsen/luenne-exxon-mobilwill-dialog-mit-erdgas-gegnern_a_1,0,655769776.html

n.a. (2011b, April 11). Gas fracking starts in Ukraine. UPI.com. Retrieved February 14, 2013, from http://www.upi.com/Business_News/Energy-Resources/2011/11/04/Gas-fracking-starts-inUkraine/UPI-86541320404322/?rel=85811327062901

n.a. (2011c, November 20). ExxonMobil: Unkonventionelle Halbwahrheiten. Der Klima-Lügendetektor. Retrieved February 25, 2013, from http://www.klima-luegendetektor.de/2011/11/20/exxonmobil-unkonventionelle-halbwahrheiten/

NaturalGasEurope.com. (2011, November 28). Exxon to Proceed with Hydraulic Fracturing in Poland. Retrieved July 14, 2013, from $\mathrm{http} / / / \mathrm{www}$.naturalgaseurope.com/exxonmobil-poland-hydraulic-fracturing

NaturalGasEurope.com. (2012a, June 18). Polish Government “Understands" ExxonMobil Withdrawal. Retrieved February 16, 2013, from http://www.naturalgaseurope.com/exxon-poland-shale-gas-withdrawal

NaturalGasEurope.com. (2012b, June 20). ExxonMobil Leaves Poland Guessing. Retrieved July 14, 2013, from http://www.naturalgaseurope.com/exxonmobil-leaves-poland-shale-gas

NaturalGasEurope.com. (2012c, October 5). Breaking the Silence: Unconventionals in Hungary. Retrieved May 14, 2013, from $\mathrm{http}: / / \mathrm{www}$. naturalgaseurope.com/unconventional-gas-in-hungary6121

NaturalGasEurope.com. (2012d, October 16). Poland Unveils Shale Ga Taxation and Regulatory Legislation. Retrieved July 14, 2013, from http://www.naturalgaseurope.com/poland-shale-gas-taxation-legislation

NDR (2011). ExxonMobil und die verschwiegene Umweltverschmutzung in Niedersachsen. Retrieved from http://www.youtube.com/watch?v=zMbgSfXIN2o\&feature $=$ youtube_gdata_player

O'Keefe, B. (2012, 16 April). Exxon's big bet on shale gas. Fortune / CNN Brainstorm Green [blog]. Retrieved 27 November 2013 from http://tech.fortune.cnn.com/2012/04/16/exxon-shale-gas-fracking/

Panorama. (2011, March 3). Exxon: US-Konzern vergiftet Grundwasser in Norddeutschland. DasErste.de. Retrieved June 23, 2011, from http://daserste.ndr.de/panorama/archiv/2011/exxon133.html

Petersdorff, W. von (2013, May 28). Umstrittene Methode: Fracking müssen wir da mitmachen? FAZ.net. Retrieved July 14, 2013, from http://www.faz.net/aktuell/wirtschaft/wirtschaftspolitik/energiepolitik/umstrittene-methode-fracking-muessen-wir-da-mitmachen12194963.html

Reuters. (2011, October 30). Ukraine signs shale gas deal with ExxonMobil. Retrieved July 14, 2013, from http://www.reuters.com/article/2011/09/30/exxonmobil-ukraine-idUSL5E7KU0UP20110930

Schmitz, M. (2012, August 11). BDEW-Positionierung zum Fracking. Presented at the 3. Sächsisches DVGW-Bezirksgruppentreffen Unkonventionelle Gasvorkommen Betrachtungen aus Sicht der Gasversorgung und der Wasserwirtschaft, Freiberg. Retrieved from http://www.dbi-gti.de/fileadmin/downloads/5 Veroeffentlichungen/Tagungen_Workshops/2012/DVGW-

BGT_2012/03_Schmitz_BDEW.pdf
Scott, M. (2013, April 24). Europe struggles in shale gas race. Retrieved July 12, 2013, from http://www.nytimes.com/2013/04/25/business/energy-environment/europe-faces-challenges-in-effort-to-embrace-shalegas.html? $r=1 \&$

Seyfert, G. (2012, March 5). Pseudo-Info-Dialog zum Fracking: Entscheidende Fragen nicht gestellt. die tageszeitung. Retrieved from http://www.taz.de/!92713/

Shale Gas Europe. (2013a). Germany. Retrieved July 14, 2013, from http://www.shalegas-europe.eu/en/index.php/resources/shale-opportunities-in-europe/germany

Shale Gas Europe. (2013b). Poland. Retrieved July 14, 2013, from http://www.shalegas-europe.eu/en/index.php/resources/shale-opportunities-in-europe/poland

Speak, C. (2013, June 12). Poland rethinks its strategy for shale gas production. Retrieved July 14, 2013, from http://www.praguepost.com/news/16488-poland-rethinks-its-strategy-for-shale-gas-production.html

Sreekumar, A. (2013, June 29). How Shale Gas Development Can Go Wrong. Retrieved July 14, 2013, from http://www.fool.com/investing/general/2013/06/29/poland-how-shale-gas-development-can-gowrong.aspx

Strzeleck, M. (2013, July 2). Fracking Boom Delayed by Kites as Poland Seeks Gas Independence. Retrieved July 14, 2013, from http://www.bloomberg.com/news/2013-02-08/fracking-boom-delayedby-kites-as-poland-seeks-gas-independence.html

Tenbrock, C. (2011, 7 June). Sperrige Bürger. Die Zeit 23. Retrieved 27 November 2013 from http://www.zeit.de/2011/23/Muenster-Energie

Theurer, M. (2013, February 1). „Fracking“: Das Schiefergas spaltet Europa. Frankfurter Allgemeine, Wirtschaft. Retrieved July 12, 2013 , from http://www.faz.net/aktuell/wirtschaft/fracking-das-schiefergasspaltet-europa-12012296.htm

Trefis Team. (2011, October 3). Exxon Starts Fracking Hard In Eastern Europe - Forbes. Retrieved July 14, 2013, from http://www.forbes.com/sites/greatspeculations/2011/10/03/exxonstarts-fracking-hard-in-eastern-europe/

Tuohy, E. \& Bulakh, A. (2013, April 23). Shale Gas Perspectives for Ukraine: Where Does Illusion End and Reality Begin? NaturalGasEurope. Retrieved May 13, 2013, from http://www.naturalgaseurope.com/shale-gas-perspectives-ukraine

Vassiliou, M. S. (2009). Historical dictionary of the petroleum industry. Lanham, Md: Scarecrow Press. 